\title{
Identification and ranking the effective factors for export promotion in pharmaceutical compa- nies
}

\author{
Sahar Zare Joneghania and Homeira Zare Joneghani ${ }^{{ }^{*}}$
}

'Master's in Economic Development and Planning, Alzahra University, Tehran, Iran

${ }^{b}$ Master's in International Commercial Management, South Branch, Islamic Azad University, Tehran, Iran

\section{CHRON I CLE A B S T RACT}

Article history:

Received: October 7, 2018

Received in revised format: No-

vember 29, 2018

Accepted: December 16, 2018

Available online:

December 25, 2018

Keywords:

Export

Economic development

DEMATEL

AHP

Pharmaceutical companies

\begin{abstract}
Nowadays, there is a growing attention on export activities and they are considered as a good strategy for companies to grow from supportive domestic sales to foreign developing markets, while offering greater flexibility, cost, and lowering different risks compared to other external development methods. With the internationalization of the global economy, the focus has been on improving export performance, which reflects the company's success in the economic field. An important point about Iran's exports, which should not be overlooked, is the decline on the reliance of the national economy on revenues from oil exports and the achievement of economic independence. Therefore, support for the export industries, especially non-oil exports, is one of Iranian priorities for increasing economic growth and creating foreign exchange earnings. In the meantime, the economic performance of pharmaceutical companies is very important because the growth and development of this sector and the export of these products bring significant foreign exchange earnings. This paper focuses on the data gathered from the managers and exporters of the pharmaceutical companies and using some statistical tests to determine the effective components on export promotion. The study considers 18 factors and extracts five important factors including profitability and economic growth, developmental quality, encouragement and financial performance. The study also uses analytical hierarchy process (AHP) and DEMATEL techniques to rank these factors and their sub-components. Quality is considered as the most important factor according to the implementation of AHP and profitability and economic growth are determined to be the most influencing factors according to DEMATEL.
\end{abstract}

C 2019 by the authors; licensee Growing Science, Canada

\section{Introduction}

The intensification of world-class competition has led more companies to seek for opportunities in international markets to achieve their goals, as well as to maintain their market position and survive. Exports are traditionally the most popular entry into international markets, especially for small and medium-sized enterprises (SMEs). In its most basic form, exports requires the access to some facilities such as human resources, financial resources and other strategic activities. However, achieving success in export markets is not easy due to the unique nature of the external environment. In almost all developing countries, the issue of promoting exports is at the top of government priorities and policies and there is a growing awareness and attention to the importance of exports in developed countries too.

* Corresponding author.

E-mail address: saho84@rocketmail.com (H. Zare Joneghani) 
Governments play a key role in fostering domestic business through the export development programs. There are various tools for encouraging and promoting exports, including supportive measures such as tax breaks, tariff reductions for import of raw materials, marketing aids, insurance protections, export guarantees, direct subsidies (cash) and indirect export, etc. The foreign sector of Iran's economy in general and Iran's non-oil exports are particularly suffering from a set of backwardness. In order to achieve sustainable development in exports, Iran must, at least, define and implement a comprehensive export development program, and because of the importance of exports, governments typically support export business by using incentives and support programs that encourage incentives exports. Hence, numerous governmental and nonprofit governmental organizations in Iran, use a variety of export promotion programs and support export activities of companies. The purpose of these programs is to improve the economic performance of the companies or encourage them to start exporting activities.

One of the trade policies used to encourage exports by governments is supportive policies, one of which is the subsidized export subsidy, which would be allocated to the related industries to boost exports. This is accomplished by compensating part of the cost of producing these goods and reducing the prices of the exported items to create a marginal deficit for the manufacturing industry compared with other similar industries and ensure the continuity of growth and the development of the early stages of development. In other words, the domestic product in the world market is priced at a lower price, competitive with other similar products. Supportive and subsidized policies began in Iran in 1933 and were first assigned to wheat and bread, and included some other essential commodities. By 1945, the purpose of government intervention was to support farmers, as well as to provide wheat storage and to emphasize that cheap bread was made for low-income urban consumers. Since 1968, when the rapid growth of the country's oil revenues began, a kind of economic policy of protecting consumers through oil revenues of the government in Iran was developed and expanded. This policy has continued since the Islamic Revolution due to ups and downs in oil revenues of the country and has continued so far. Subsidies are one of the major support measures of governments that are being used to support consumers, producers and exporters. Generally speaking, subsidies as government grants, which, firstly, allow the consumer to buy goods and services at prices below the market price, and secondly, increase producers' incomes compared to non-state intervention or reduce production costs. The present decade has been distinguished by the rapid internationalization of businesses and the emergence of global competition. Consumer goods markets, industrial goods and services are integrated with world-class industries such as capital, materials and technology, and at the same time, the formation of diversified business agreements and the establishment of open trade policies by developed and developing countries have led to the imposition of protectionist measures and barriers.

Perhaps one of the important reasons for increasing export attention can be found in the balance-ofpayments word, as most countries have experienced the deficit-alleviation of payments in real terms or in the form of a mere forecast. Today, this is a rule that increased exports of a country can dramatically lead to export expansion or internationalization as the only way to survive and grow. Another major reason for increasing export inclination may be the change in the world economy. This change is attributed to the spread of new technology around the world, the reduction of trade barriers, the formation of multilateral trade agreements between countries in the world (such as GATT, NAFTA and the EU), financial market regulation, and the tightness of customers' tastes and globalization in general.

Countries also encourage their companies to export, as this important activity increases employment in the interior, develops competitive conditions and improves foreign exchange earnings. Profitability is also one of the major export advantages. Other export benefits include flexibility and improved ability to handle sales volatility in the domestic market. The emergence of a world without borders, which facilitates the free flow of information and resources, is like a double-edged sword, which creates opportunities and conflicts with many threats. In general, the benefits of companies with foreign sales are as follows:

1. Achieve foreign exchange earnings; 
2. Increasing the level of employment and tackling unemployment;

3. Improving the quality of manufactured goods due to competition in international markets and improving internal management in dealing with foreign competitors;

4. Reduced production costs due to increased production capacity and scale savings;

5. Strengthening the economy of the country;

6. Rising GDP and rising per capita income;

7. Expand social welfare;

8. Increasing the country's share in global trade and promoting international credibility;

9. Earns more profits;

10. Enables the company to operate in different markets, in different quality, or to sell their products.

Of all the factors affecting the country's economic performance, there may be one of the factors behind the export promotion program. Achieving good understanding of these programs will help policy makers in the country's export and international trade to more intelligently select a variety of export promotion programs and allocate limited public resources to supportive programs that would have a greater impact on the company's export performance. In Iran, significant amount of investment are devoted annually on export promotion programs. However, despite the fact that for several decades, the strategy of encouraging exports has been one of the main strategies for macroeconomic growth policy on the agenda of the Iranian government, several programs and activities have been carried out in this regard.

\section{Export Promotion Measures}

The most common export promotion measures are export sales levels, export intensity, and export profitability (Katsikeas et al., 2000). Companies with higher economic performance normally meet the criteria for higher export performance. Although several broad approaches have been introduced for measuring export capabilities, researchers have used unique names for export performance measurement metrics. By revising these criteria, measurements are grouped into seven classes, which are based on financial, non-financial scales, and scales. Combination are shown:

\subsection{Financial metrics}

These criteria represent the financial measures of export performance, which are mainly derived from the financial statements. Export performance is usually measured using the unit index approach, and export sales, export sales growth, export profits, and export intensity (export to sales ratio) are the most commonly used indices (Zou \& Stan, 1998).

- Sales metrics: measures the volume of export sales or export intensity.

- Income criteria: Includes criteria that measure the total profit of exports, and include relative measures such as export earnings divided by total export profits or export profits divided by domestic market profits.

- Growth Criteria: the change in sales or export profits over a period of time.

The majority of study criteria used for the export of products are only financial indicators (for example, export sales, export profitability, and export market share). When, in a long period of time, firms are not be able to export, they will not be able to achieve financial goals, so many firms will pursue other goals for export (Durmuşoğlu et al., 2012).

\subsection{Non-financial criteria}

Compared to financial criteria that can be objectively measured, non-financial criteria are more subjective, including three criteria for perceived success, satisfaction, and achievement of the goal.

- Benchmark for success: The benchmark for success includes criteria such as the belief that export conducts more profit and more reputation for the company.

- Satisfaction criterion: These criteria are related to the general satisfaction of the manager of the company's export performance. 
- Objectives: To assess the performance of the manager compared with the goals.

2.3. Hybrid criteria

Hybrid measures are preferable because they provide a more complete picture of performance and show different aspects of the performance, each of which may be influenced by specific features of the firms (Leonidou et al., 2002). Therefore, this study uses the hybrid measures of export performance in the form of subjective words to assess the level of achievement of export objectives perceived by managers. These criteria are based on the overall score of a wide variety of performance criteria. Among the above categories, sales benchmarks, profits, and composite metrics are most often used in research on export performance (Zou \& Stan, 1998). The criteria mentioned are among the most important tools for measuring the performance of export promotion, even though there are clear criteria for measuring the performance of export promotion, it is difficult to measure them, complexities are due to different reasons, such as:

1. Firms usually do not report financial details of their export activities.

2. It is difficult to obtain archived data in this area; export performance is mainly based on financial statements, and different local and national accounting standards are difficult to compare in various societies.

3. National and local factors affect managers' perceptions and satisfaction with the level of performance achieved.

4. It is difficult to assess the costs of exporting their products because these costs are inherently dependent on the company's look at their export activities.

5. The major performance measures examined in studies have been mental or perceptual assessments that have been carried out by managers responsible for export operations,

These reasons cause the ambiguity that results from the inaccuracy of these criteria. Some of these ambiguities include the failure to disclose secret information for strangers, the lack of an accounting mechanism in exporting companies to properly disclose export sales and other information (Xiongyuan \& Shan, 2013).

\section{The proposed study}

The purpose of this paper is to identify the effective factors in exporting promotion, which is a descriptive surveying type. This study was conducted by designing a questionnaire for managers and experts in the pharmaceutical companies' export sector in Tehran, Iran based on the Likert spectrum. The questionnaires were distributed among 185 experts who were involved in pharmaceutical industry. In addition, this paper uses factor analysis to study data. Alpha Cronbach was calculated as $86 \%$, which is considered as an appropriate reliability for the research questionnaire. Since factor analysis is sensitive to the Skewness of the factors, some questions were removed from the questionnaire and 18 variables were confirmed. In 5 factors, the content validity of the variables was distributed randomly among the samples in the form of a questionnaire. After collecting and performing Bartlett's test, its validity was 0.83 , which was a good narrative for research. Table 1 demonstrates the results of KMO test. As we can observe from the results of Table 1, Bartlett's Test of Sphericity yields an approximate Chi-Square of 1484.886 which is meaningful when the level of significance is one percent.

\section{Table 1}

The results of KMO and Bartlett's Test

\begin{tabular}{lcc}
\hline Kaiser-Meyer-Olkin Measure of Sampling Adequacy. & 0.83 \\
\hline Bartlett's Test of Sphericity & Approx. Chi-Square & 1484.886 \\
& Df & 153 \\
& Sig. & 0.000 \\
\hline
\end{tabular}




\subsection{Factor analysis}

We first present the results of the implementation of the factor analysis for detecting important criteria influencing on export activities. Table 2 demonstrates the results of total variance explained.

Table 2

The summary of the results of Total Variance explained

\begin{tabular}{|c|c|c|c|c|c|c|c|c|c|}
\hline \multirow[b]{2}{*}{$\begin{array}{l}\S \\
\frac{8}{0} \\
\stackrel{8}{8} \\
\cong\end{array}$} & \multicolumn{3}{|c|}{ Initial Eigenvalues } & \multicolumn{3}{|c|}{ Extraction Sums of Squared Loadings } & \multicolumn{3}{|c|}{ Rotation Sums of Squared Loadings } \\
\hline & Total & $\begin{array}{c}\% \text { of } \\
\text { Variance }\end{array}$ & $\%$ Cumulative & Total & $\begin{array}{c}\% \text { of } \\
\text { Variance }\end{array}$ & \%Cumulative & Total & $\begin{array}{c}\% \text { of } \\
\text { Variance }\end{array}$ & \%Cumulative \\
\hline 1 & 5.497 & 30.537 & 30.537 & 5.497 & 30.537 & 30.537 & 2.565 & 14.252 & 14.252 \\
\hline 2 & 1.790 & 9.942 & 40.479 & 1.790 & 9.942 & 40.479 & 2.365 & 13.137 & 27.389 \\
\hline 3 & 1.372 & 7.624 & 48.103 & 1.372 & 7.624 & 48.103 & 2.081 & 11.564 & 38.953 \\
\hline 4 & 1.293 & 7.186 & 55.289 & 1.293 & 7.186 & 55.289 & 2.073 & 11.517 & 50.469 \\
\hline 5 & 1.069 & 5.936 & 61.225 & 1.069 & 5.936 & 61.225 & 1.936 & 10.756 & 61.225 \\
\hline
\end{tabular}

In this article, five factors including development, quality, profitability and economic growth, functional-financial, and incentive are considered. Table 3 demonstrates the summary of the five factors and sub-component.

\section{Table 3}

The summary of components, variables and factors of variables related to the factors affecting economic performance

\begin{tabular}{|c|c|c|c|c|}
\hline item & Variable & Component & Variable number & Factor loading \\
\hline 1 & R \& D Subsidy & \multirow[t]{4}{*}{ Developmental } & 1 & 0.783 \\
\hline 2 & Export subsidies & & 3 & 0.798 \\
\hline 3 & Energy subsidies & & 17 & 0.634 \\
\hline 4 & Government subsidy for new technology & & 7 & 0.469 \\
\hline 5 & Product quality & \multirow[t]{3}{*}{ Quality } & 16 & 0.698 \\
\hline 6 & Products and processes of high technology & & 12 & 0.766 \\
\hline 7 & Corporate Innovation Activities & & 13 & 0.507 \\
\hline 8 & Economic performance of the company & \multirow{5}{*}{$\begin{array}{l}\text { Profitability and economic } \\
\text { growth }\end{array}$} & 18 & 0.525 \\
\hline 9 & The amount of investment & & 2 & 0.421 \\
\hline 10 & Profitability & & 4 & 0.579 \\
\hline 11 & Access to foreign sources & & 11 & 0.732 \\
\hline 12 & Sustainable economic growth & & 8 & 0.638 \\
\hline 13 & company's performance & \multirow[t]{3}{*}{ Functional-financial } & 10 & 0.626 \\
\hline 14 & Promote high-performance projects & & 9 & 0.77 \\
\hline 15 & Export Costs & & 14 & 0.681 \\
\hline 16 & Export Promotion Policies & \multirow[t]{3}{*}{ Encouragement } & 15 & 0.615 \\
\hline 17 & Support and promotion of domestic & & 6 & 0.73 \\
\hline 18 & Export Promotion Policy & & 5 & 0.785 \\
\hline
\end{tabular}

As we can see in Table 4, according to the values of t-student, which are all greater than 1.96, the explanation of export promotion is confirmed by developmental components, quality, profitability, and economic, financial, and incentive growth.

\section{Table 4}

The results of t-student test on five factors influencing on export activities

\begin{tabular}{lccc}
\hline Variable & $\mathrm{t}$ & Sig. (2-tailed) & Results \\
\hline Developmental factors & 27.747 & .000 & Confirmed \\
Quality & 25.459 & .000 & Confirmed \\
Profitability and economic growth & 33.215 & .000 & Confirmed \\
Functional-financial & 26.557 & .000 & Confirmed \\
Encouragement and incentive growth & 29.627 & .000 & Confirmed \\
\hline
\end{tabular}




\subsection{Ranking alternatives}

\subsubsection{Analytical hierarchy process}

During the past few decades, there have been tremendous efforts on developing various criteria for ranking alternatives. Analytical hierarchy process (AHP) (Saaty, 1981, 1987) is one of the well-known methods which has been widely implemented for various purposes. In this survey, after analyzing the necessary factors and identifying the effective components of export promotion, we have analyzed the criteria and indicators for the economic performance of drug companies using the AHP technique. The summary of the results is shown in Table 5.

\section{Table 5}

The results of the implementation of AHP method

\begin{tabular}{|c|c|c|c|}
\hline Criteria & Weight & Attribute & Final \\
\hline \multirow{5}{*}{$\begin{array}{l}\text { Profitability and } \\
\text { economic growth }\end{array}$} & \multirow{5}{*}{0.125} & The amount of investment & 370 \\
\hline & & Profitability & 0.194 \\
\hline & & Sustainable economic growth & 0.228 \\
\hline & & Access to foreign sources & 0.149 \\
\hline & & Economic performance of the company & 0.059 \\
\hline \multirow{3}{*}{ Encouragement } & \multirow{3}{*}{0.114} & Export Promotion Policies & 0.325 \\
\hline & & Export Promotion Policies & 0.518 \\
\hline & & Support and promotion of domestic industries against foreign competition & 0.156 \\
\hline \multirow{3}{*}{ Quality } & \multirow{3}{*}{0.525} & Products and processes of high technology companies & 0.089 \\
\hline & & Company Innovation Activities & 0.239 \\
\hline & & quality of products & 0.619 \\
\hline \multirow{4}{*}{ Developmental } & \multirow{4}{*}{0.131} & R \& D Subsidy & 0.366 \\
\hline & & Export subsidies & 0.182 \\
\hline & & Government subsidy for new technology development & 0.173 \\
\hline & & Energy subsidies & 0.28 \\
\hline \multirow{3}{*}{ Functional-financial } & \multirow{3}{*}{0.105} & Promote high-efficiency projects & 0.271 \\
\hline & & company's performance & 0.579 \\
\hline & & Export Costs & 0.15 \\
\hline
\end{tabular}

As we can observe from the results of Table 5, quality is the most important factor for export development followed by developmental factors, profitability and economic growth, encouragement and financial factors. In our survey, consistency ratio was 0.04 , which is well below the acceptable level of 0.1 and this confirms the results of AHP.

\subsubsection{DEMATEL}

DEMATEL is used to analyse qualitative data related to the characteristics of objectives, which demonstrates the structure of a hierarchical decision problem. Using DEMATEL technique, we may determine the independence of each attribute and the cause and effect linkages with the operational and strategic objectives for export development (See Wu et al., 2010 for more details on DEMATEL). Table 6 demonstrates the summary of input factors.

\section{Table 6}

The summary of the cause and effect patterns

\begin{tabular}{ccccc}
\hline $\mathrm{m}$ & $\mathrm{D}$ & $\mathrm{R}$ & $\mathrm{D}+\mathrm{R}$ & $\mathrm{D}-\mathrm{R}$ \\
\hline Profitability and economic growth & 1.6 & 3.01 & 4.61 & -1.41 \\
Encouragement & 2.24 & 1.16 & 3.4 & 1.09 \\
Quality & 1.81 & 2.49 & 4.3 & -0.68 \\
Developmental & 1.95 & 1.84 & 3.79 & 0.11 \\
Functional-financial & 2.05 & 1.16 & 3.2 & 0.89 \\
\hline
\end{tabular}


In Table 6, the sum of the elements of each row (D) indicates the extent of its effect on other factors. Developmental factors have the greatest impacts on other elements. The sum of column elements (R) for each factor indicates the effect of its factor on other system factors. The factors of profitability and economic growth are most influential from the other elements. Horizontal vector $(D+R)$ is the amount of effect. Profitability and economic growth have the most interaction with other elements. Vertical vector (D-R) shows the power of the effect of each factor. In general, if a D-R is positive, the variable is a causal variable, and if it is negative, it is considered an effect. Quality factors and factors of profitability and economic growth are other causative factors. Table 7 demonstrates the results of the influence and

\section{Table 7}

The cause and effect pattern of Sub-Components

\begin{tabular}{lcccc}
\hline $\mathrm{T}$ & $\mathrm{D}$ & $\mathrm{R}$ & $\mathrm{D}+\mathrm{R}$ & $\mathrm{D}-\mathrm{R}$ \\
\hline The amount of investment & 366.08 & 364.53 & 730.61 & 1.55 \\
Profitability & 374.22 & 363.14 & 737.36 & 11.08 \\
\hline Sustainable economic growth & 364.27 & 381.83 & 746.1 & -17.56 \\
\hline Access to foreign sources (financial) & 369.2 & 373.46 & 742.66 & -4.26 \\
Economic performance of the company & 371.6 & 374.03 & 745.63 & -2.43 \\
R \& D Subsidy & 362.06 & 365.51 & 727.57 & -3.45 \\
Export subsidies & 368.79 & 377.5 & 746.29 & -8.71 \\
Government subsidy for new technology development & 379.95 & 365.35 & 745.3 & 14.6 \\
Energy subsidies & 378.36 & 360.17 & 738.53 & 18.19 \\
Products and processes of high technology companies & 367.87 & 365.52 & 733.39 & 2.35 \\
Corporate Innovation Activities & 371.94 & 370.72 & 742.66 & 1.22 \\
Quality of products & 365.13 & 364.09 & 729.22 & 1.04 \\
Export Promotion Policies & 370.89 & 378.24 & 749.13 & -7.35 \\
\hline Support and promotion of domestic industries against foreign competition & 383.94 & 372.36 & 756.3 & 11.58 \\
Export Promotion Policy & 357 & 372.47 & 729.47 & -15.47 \\
Promote high-performance projects & 374.28 & 376.94 & 751.22 & -2.66 \\
Company's performance & 374.82 & 375.7 & 750.52 & -0.88 \\
\hline Export Costs & 364.99 & 363.83 & 728.82 & 1.16 \\
\hline & & &
\end{tabular}

\section{Table 8}

The summary of cause and effect factors

\begin{tabular}{|c|c|c|c|c|c|}
\hline & $\mathrm{D}+\mathrm{R}$ & & $\mathrm{T}$ & D-R & \multirow{19}{*}{ 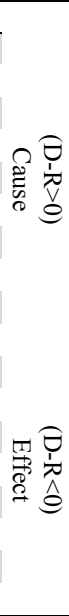 } \\
\hline R \& D Subsidy & 727. & & Energy subsidies & 18.1 & \\
\hline Export Costs & 728. & & Government subsidy for new technology development & 14.6 & \\
\hline quality of products & 729. & & Support and promotion of domestic industries against & 11.5 & \\
\hline Export Promotion Policy & 729. & \multirow{15}{*}{ 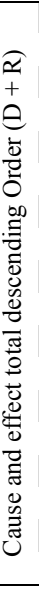 } & Profitability & 11.0 & \\
\hline The amount of investment & 730. & & Products and processes of high technology companies & 2.35 & \\
\hline Products and processes of high technology companies & 733. & & The amount of investment & 1.55 & \\
\hline Profitability & 737. & & Corporate Innovation Activities & 1.22 & \\
\hline Energy subsidies & 738. & & Export Costs & 1.16 & \\
\hline Access to foreign sources & 742. & & quality of products & 1.04 & \\
\hline Corporate Innovation Activities & 742. & & company's performance & 0.88 & \\
\hline Government subsidy for new technology development & 745. & & Economic performance of the company & 2.43 & \\
\hline Economic performance of the company & 745. & & Promote high-performance projects & 2.66 & \\
\hline Sustainable economic growth & 746. & & R \& D Subsidy & 3.45 & \\
\hline Export subsidies & 746. & & Access to foreign sources & 4.26 & \\
\hline Export Promotion Policies & 749. & & Export Promotion Policies & 7.35 & \\
\hline company's performance & 750. & & Export subsidies & 8.71 & \\
\hline Promote high-performance projects & 751. & & Export Promotion Policy & 15.4 & \\
\hline Support and promotion of domestic industries against & 756. & & Sustainable economic growth & 17.5 & \\
\hline
\end{tabular}

According to Table 8, the four factors of energy subsidy, government subsidy for developing new technology, supporting and promoting domestic industries against external competition and profitability account for the highest weight of total D-R values. This means that these factors have the most causative factors compared with other factors. Also, the last four factors including sustainable economic growth, export promotion policy, export subsidies and export promotion policies are 
accounted for the highest percentages of total negative amounts, which means that these factors are the most effective factors by other factors.

\section{Conclusion}

Despite the fact that most developing countries are trying to bring their economies closer to the free market and thus bring themselves together on the world stage, there are also countries that subsidize and assist the domestic industries. These funds encourage investment and help the economy, employment and capital, increase social welfare, and can also develop the activities of manufacturing and exporting companies. In the meanwhile, export of the pharmaceutical sector is of great importance because the growth of this sector means the growth of economic performance of the country and the export of these products also bring significant foreign exchange earnings. The purpose of this study was to identify the factors affecting export promotion on economic performance of Iranian drug companies to improve the economic performance. In this study, using the DEMATEL and AHP approach, the significance of each factor and the most important factors affecting export promotion was prioritized. According to the AHP technique, quality with a normalized weight of 0.555 was nominated as the highest priority while according to DEMATEL technique, the cause and the effect of the desired factor have disclosed that profitability and economic growth were the most important factors.

\section{References}

Durmuşoğlu, S. S., Apfelthaler, G., Nayir, D. Z., Alvarez, R., \& Mughan, T. (2012). The effect of government-designed export promotion service use on small and medium-sized enterprise goal achievement: A multidimensional view of export performance. Industrial marketing management, 41(4), 680-691.

Katsikeas, C. S., Leonidou, L. C., \& Morgan, N. A. (2000). Firm-level export performance assessment: review, evaluation, and development. Journal of the Academy of Marketing Science, 28(4), 493-511.

Leonidou, L. C., Katsikeas, C. S., \& Samiee, S. (2002). Marketing strategy determinants of export performance: a meta-analysis. Journal of Business research, 55(1), 51-67.

Saaty, T. L. (1981). Decision Making for leaders: The analytical hierarchy process for decisions in a complex work. Lifetime Learning Publications.

Saaty, R. W. (1987). The analytic hierarchy process - what it is and how it is used. Mathematical Modelling, 9(3-5), 161-176.

Wu, W.-W., \& Lee, Y.-T. (2007). Developing global managers' competencies using the fuzzy DEMATEL method. Expert Systems with Applications, 32(2), 499-507.

Xiongyuan, W., \& Shan, W. (2013). Chairman's government background, excess employment and government subsidies: evidence from Chinese local state-owned enterprises. China Journal of Accounting Research, 6(1), 51-74.

Zou, S., \& Stan, S. (1998). The determinants of export performance: a review of the empirical literature between 1987 and 1997. International Marketing Review, 15(5), 333-356.

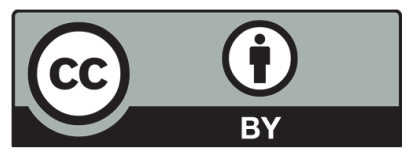

(C) 2019 by the authors; licensee Growing Science, Canada. This is an open access article distributed under the terms and conditions of the Creative Commons Attribution (CC-BY) license (http://creativecommons.org/licenses/by/4.0/). 